\title{
Impact of Adopting International Financial Reporting Standards: Empirical Evidence from Turkey
}

\author{
Serkan Terzi ${ }^{1}$, Recep Oktem ${ }^{2} \&$ Ilker Kiymetli Sen ${ }^{3}$ \\ ${ }^{1}$ Department of Accounting and Finance, Cankiri Karatekin University, Cankiri, Turkey \\ ${ }^{2}$ Department of Accounting Tax, Marmara University, Istanbul, Turkey \\ ${ }^{3}$ Department of Accounting and Auditing, Istanbul Ticaret University, Istanbul, Turkey \\ Correspondence: Serkan Terzi, Faculty of Economics and Administrative Sciences, Department of Business \\ Administration, Ismail Hakki Karadayi Street, Cankiri, Turkey. Tel: 90-376-213-2626. E-mail: \\ serkanterzi@karatekin.edu.tr
}

Received: January 11, 2013

Accepted: February 25, 2013

Online Published: March 11, 2013

doi:10.5539/ibr.v6n4p55

URL: http://dx.doi.org/10.5539/ibr.v6n4p55

\begin{abstract}
In this study, the impact of adopting International Financial Reporting Standards (IFRSs) on listed companies in Turkey was examined. We observed the financial statements that were prepared in accordance with IFRS and local GAAP and researched the standards which included more relevant information. We worked on the financial statements of the companies in the Istanbul Stock Exchange (ISE) that operated in the manufacturing industry. In our findings, we determined that the financial statements prepared in accordance with local GAAP and IFRS were statistically different. Significant differences were identified in inventories, fixed asset, long term liability and stockholders' equity accounts in the financial statements. In addition, current ratios, receivables turnover ratios, asset turnover ratios, total liabilities/tangible assets, fixed assets turnovers, equity turnover rates, short term liabilities/total debts and short term liabilities/total assets ratios based on IFRS financial statements were statistically and significantly distinguished from the stated ratios of local GAAP financial statements. We were unable to observe statistically significant differences in book value/market value ratio analysis depending on the market value under local GAAP and IFRS. However, in subsector analysis, we identified that some subsector groups have been affected from the transition to IFRS.
\end{abstract}

Keywords: international financial reporting standards, financial ratio, relevance of financial information, Istanbul Stock Exchange

\section{Introduction}

Political factors, economical factors, volume of foreign trade, and culture of the country and structure of enterprises management are the factors that form the accounting practice in a country (Karapinar et al., 2012). These variations played a significant role in international convergence in financial reporting for the last few years, and the International Accounting Standards Board (IASB) discussed these differences as priorities and European Union supported the convergence process strongly. The main reason of the convergence is to achieve the comparability and consistency in financial reporting (Terzi, 2011).

In order to establish global accounting standards, the IASB published IFRSs. Previously, the International Accounting Standards Committee (IASC) issued International Accounting Standards (IASs).

The IASB's published standards are harmonized in many countries all around the world. For example, the listed companies of 27 member countries of the European Union prepare their financial statements in conformity with IFRSs, instead of local GAAP. Many countries in Africa, Asia, Australia and America integrate their local GAAP to IFRS (Mirza et al., 2006; Terzi, 2011). Today, more than 100 countries authorize the implementation of IFRS (Guggiola, 2010).

The purpose of this study is to evaluate the effects of convergence in mandatory and voluntary IFRSs in financial statements and in value relations. Due to this purpose, we analyzed the listed manufacturing companies in the ISE. The reason for the selection of manufacturing companies is the industry's wide impact on IFRSs. In fact, many standards are applied by the manufacturing companies. 
Financial reporting is relevant when it affects the economic decisions of investors, employees, creditors, and customers. In our study, we used book value/market value ratio in order to assess this relationship.

\section{Review of the Literature}

In recent years, various empirical researches have been conducted on the effects of mandatory and voluntary IFRS conversion from local GAAP. In these studies, the effects of IFRS transition in the European Union countries were mostly examined. (Harris et al., 1994; Niskanen et al., 2000; Arce \& Mora, 2002; Jermakowicz, 2004; Callao et al., 2007; Haverals, 2007; Jermakowicz et al., 2007; Lantto \& Sahlström, 2009; Gaston et al., 2010; Iatridis, 2010; Jarva \& Lantto, 2010; Zeghal et al., 2011).

The recent studies on IFRS can be classified into two groups. The first one is about the analysis focusing on the impact of IFRS adoption within the scope of local accounting systems (Jermakowicz, 2004; Agca \& Aktas, 2007; Callao et al., 2007; Lantto \& Sahlström, 2009; Gaston et al., 2010; Iatridis, 2010; Kabir et al., 2010). These studies generally use descriptive statistics, paired two-group tests (independent samples $t$ test for parametric data, Wilcoxon signed rank test for non-parametric data), and regression analysis. The second group involves studies about the effects of different accounting principles on value relevance of accounting information. (Harris et al., 1994; Harris \& Muller, 1999; Niskanen et al., 2000; Arce \& Mora, 2002; Callao et al., 2007; Hung \& Subramanyam, 2007; Jermakowicz et al., 2007; Gaston et al., 2010; Jarva \& Lantto, 2010; Zeghal et al., 2011). For this purpose, the book values that are based on local accounting systems and IFRS are compared with market values of these.

The listed companies in the European Union first prepared their mandatory financial statements in accordance with IFRS in 2005 (E.U. Regulation No.1606/2002). With the issuance of a decree (Series XI, No: 25) by the Capital Markets Board of Turkey (CMB), the listed companies in Turkey first prepared their financial statements in accordance with IFRS voluntarily in 2003, and the mandatory application of IFRS started in 2005. There are only a limited number of studies in Turkey about the effects of the transition to IFRS. The national and international researchers have studied the effects of transition to IFRS and have investigated the differences of local accounting regulations and IFRS. In this context, some of the related studies were examined (Harris et al., 1994; Harris \& Muller, 1999; Niskanen et al., 2000; Arce \& Mora, 2002; Jermakowicz, 2004; Agca \& Aktas, 2007; Callao et al., 2007; Haverals, 2007; Hung \& Subramanyam, 2007; Jermakowicz et al., 2007; Lantto \& Sahlström, 2009; Gaston et al., 2010; Iatridis, 2010; Jarva \& Lantto, 2010; Kabir et al., 2010; Zeghal et al., 2011).

Harris et al. (1994) compared the value relevance of German and US companies based on various criteria. As a result of this study, in contrast to the notion that accounting figures of German companies are meaningless, the figures were found to be associated with stock returns. In addition, Hung and Subramanyam (2007) studied the effects of IFRS adoption on value relevance and financial reports. Hung and Subramanyam found that book value (net income) plays a greater (lesser) valuation role under IFRS than under local GAAP. In addition, researchers discovered that while the IFRS adjustments to book value were generally value relevant, the adjustments to income were generally value irrelevant.

Harris and Muller (1999) investigated the market valuation of earnings and the book values of financial statements in accordance with IFRS and US-GAAP. According to the research, IFRS earnings per share amounts were identified to be more highly associated with prices per share than US-GAAP earnings per share amounts. However, US-GAAP-based values were found to be more associated with values of securities than IFRS-based values.

Arce and Mora (2002) investigated the value relevance of alternative accounting measures (earnings and book values) under different accounting systems in Europe. The researchers included the listed companies in Belgium, France, Germany, Italy, the Netherlands, Switzerland, Spain and the UK in the analysis, in order to examine the value relevance between these companies' earnings, book values, and market values. In addition, the authors determined whether there was a relationship between earnings and book values or not. According to the t-test, the relationship between the two variables was found to be statistically significant.

Jermakowicz (2004) examined the effects of IFRS adoption on BEL-20 companies in Belgium. The research questions related with the problems faced in adapting IFRS were sent to selected companies. The study focused on the effects of IFRS transition on financial reporting regarding the organizational, accounting and financial strategies of companies. As a result of the study, the researchers concluded that IFRS transition had significant impacts on the selected companies. Jermakowicz et al. (2007), in their study, examined the value relevance of IFRS transition effects on DAX-30 listed German companies. As a result of their study, they found that IFRS transition improved the comparability of the financial statements. In addition, they identified that there had been 
changes in earnings of the companies due to various reasons.

Agca and Aktas (2007) analyzed the results of the financial ratios gathered from the financial statements prepared in accordance with IFRS and the financial statements prepared according to the local regulations. The financial statements were obtained from the CMB and they were analyzed to identify the extent of differences of these two regulations. Companies from 5 different industries were included in their study and the authors gathered different number of observations in each sector. As a result of the study, they found that some selected variables are statistically significant.

Callao et al. (2007) investigated the impact of IFRS harmonization on the financial statements and their comparability in Spain. For this purpose, IBEX-35 companies were included in the analysis. In this study, the relationship between financial ratios and accounting figures was investigated according to local GAAP and IFRS and as a result, a statistically significant relationship was found according to the two different standards. Especially, it was noted that total liabilities, long-term liabilities, cash and cash equivalents and shareholders' equity were affected significantly from the transition to IFRS. In addition, they identified that the book values differed significantly from the market values under IFRS and under Spanish standards.

Gaston et al. (2010) studied the effects of transition from local GAAP to IFRS on accounting figures, book values and market values in Spain and in UK. In addition, they worked on the financial information quality of local GAAP-based and IFRS-based financial statements. In this study, the effects of the transition are statistically significant on reporting of both countries; however, these effects are more significant on reporting in the UK. In addition, negative impacts of IFRSs were identified in these two countries in this study. Moreover, the only significant transition effect was found in Spain.

Haverals (2007) examined the transition effects on financial reporting in accordance with IFRS based tax harmonization policy of the European Union and their effects on the tax burdens of companies in Belgium. As a result of this study, it was concluded that IFRS-based tax accounting had major influence on the tax burden of Belgian companies and the study also revealed that the impact was not uniform across sectors.

Lantto and Sahlström (2009) identified the IFRS transition effects on financial reporting in Finland with the use of financial ratios. They determined that the selected financial ratios were significantly affected as a result of the IFRS adoption. They stated that fair accounting rules and other important rules were the reasons of these significant fluctuations. Niskanen et al. (2000) are other researchers who studied on value relevance of IFRS-based financial statements. Niskanen et al. determined that earnings of companies had important effects on value relevance.

Iatridis (2010) studied the transition effects of IFRS-based financial reporting in UK with the help of certain financial ratios. In this study, Iatridis identified that IFRS adoption had significant effects on the financial performance of companies in the UK, and the fair value accounting due to the adoption of IFRS introduced volatility in income statement figures.

Jarva and Lantto (2010) compared local GAAP-based financial statements with IFRS-based financial statements. Thus, they investigated value relevance between IFRS and local GAAP. According to the research, book values of earnings, assets and liabilities under IFRS had no more value relevance than those of local GAAP. In addition, they found that IFRS earnings adjustments included no information about future cash flows.

Kabir et al. (2010) investigated the effects of IFRS adoption on accounts and earnings' quality of New Zealander companies. They identified that total assets, total liabilities and net profit figures were higher in IFRS-based financial statements. They also determined that IFRS-based adjustments increased goodwill, other intangible assets and investment property amounts. On the other hand, these adjustments caused decreases in employee benefits and share-based payments.

Zeghal et al. (2011) studied the effects of IFRS adoption on earnings management of French companies. As a result of the study, mandatory IFRS adoption caused a reduction in the earnings management level. In addition, they identified that some factors affected the IFRS adoption of French companies.

\section{Key Accounting Differences between Turkish Accounting System and IFRS}

Turkish Accounting System (TAS) was first influenced by French system, and then by German system. Due to the economic developments and politic relations between US and Turkey in the 1950s, Turkish Accounting System, was later influenced by the US accounting system. Turkey's first regulatory institution is the CMB, established in 1981. However, the CMB's jurisdiction was limited to Capital Markets Law. Following these improvements, the Ministry of Finance published the Generally Accepted Accounting Principles of Turkey, and all companies (except for some) are required to keep their books according to Uniform Chart of Accounts (Agca 
\& Aktas, 2007).

The introduction of IFRS has begun with Serial: XI, No: 25 "Communiqué on Accounting Standards in Capital Markets" in Turkey. The listed companies voluntarily prepared IFRS-based financial statements in 2003 and prepared mandatory IFRS-based financial statements in 2005 in Turkey. However, some private companies are also required to apply IFRS in their financial statements as of January 1, 2013 under the Turkish Commercial Code No.6102, which came into effect on July 1, 2012.

The listed companies prepared their financial statements in accordance with local GAAP until 2005 in Turkey. These companies prepare financial statements and reporting in compliance with the Uniform Chart of Accounts in Turkey, issued in 1994. However, listed companies started to prepare mandatory IFRS-based financial statements in 2005 (voluntary IFRS-based financial statements in 2003).

We have been able to address differences between local GAAP-based and IFRS-based financial statements in two groups. The first one is the balance sheet differences and the other one is income statement differences. The fundamental balance sheet differences are related with goodwill, investment properties, construction contracts, and provisions of trade receivable and trade payable accounts. The fundamental income statement differences are related with the classification of continuing and discontinued operations, extraordinary income and expenses, calculation of deferred income and expenses. In addition, we are able to state the differences on presentation of non-controlling interest in shareholders' equity on the balance sheet and non-controlling interest in net profit on the income statement. Also, some of the standards, such as deferred taxes, share-based payments, and derivative instruments, do not apply to the TAS. Terzi et al. (2007), Terzi (2008), Terzi et al. (2008) studied the effects of the transition on financial reporting from local GAAP to IFRS. The results supported that the affected accounts in this study were in line with the results of these studies on transition to IFRS.

Appendix 1 describes the key differences between TAS and IFRS. We have classified the differences in two groups, depending on whether the item is related to the preparation of the balance sheet, or the income statement.

\section{Research Methodology}

In this section, we present the research sample together with the method of data collection as well as the measurement of the research variables and the method of statistical analysis.

\subsection{Source of Data and Sample Size}

Financial ratios are frequently used in the accounting literature. Especially in practice, investors, creditors or business owners use these ratios. In addition, ratios provide useful information about the financial position and performance of the companies.

In our research, we included 140 manufacturing companies, listed on the Istanbul Stock Exchange (ISE). Two of the companies, which were not publicly traded, but presented their financial statements due to their number of shareholders, were not used in the study. We analyzed the selected audited financial statements and annual reports as of December 31, 2003 and December 31, 2005. The statements and reports at these dates were selected on purpose, because the companies presented voluntary IFRS-based financial statements as of December 31, 2003, and mandatory IFRS-based financial statements as of December 31, 2005. The industrial breakdowns of the selected companies are presented in Table 1.

Table 1. Sample industrial sectors

\begin{tabular}{lll}
\hline Sub-sector Codes & Sub-sectors & Num. \\
\hline FBT & Food, Beverage \& Tobacco & 19 \\
TCL & Textile, Clothing \& Leather & 26 \\
WFP & Wood, Furniture, Paper \& Printing & 11 \\
PCR & Petroleum Products, Chemicals, Rubber \& Plastics & 24 \\
STS & Stone \& Soil & 26 \\
MEI & Metal Industry & 12 \\
CER & Construction Machinery, Equipment \& Related Products & 22 \\
\hline
\end{tabular}

The Turkish listed companies that have prepared mandatory IFRS-based financial statements for the first time, were required to prepare their December 31, 2004 financial statements both in accordance with IFRS (Serial: XI, No: 25), and with historical cost-based national accounting principles that were not in conformity with IFRS (Serial XI, No: 1), and they also adjusted their financial statements for inflation in accordance with Serial XI, No: 20. In addition, the CMB published the financial statement formats that were compatible with IFRS, and 
urged listed companies to comply with these formats.

The listed companies prepared IFRS-based comparative financial statements as of December 31, 2004 and 2005 in accordance with Serial: XI, No: 25 Communiqué. Early IFRS adopted listed companies prepared comparative financial statements of December 31, 2002 and 2003. Therefore, financial statements of December 31, 2002 and 2004 were prepared in accordance with both IFRS and local GAAP.

These circumstances helped us to determine the statistically significant differences among different accounting principles.

The purpose of this study is to identify the statistically significant differences between local GAAP-based and IFRS-based financial statements of manufacturing companies listed on ISE in terms of financial statement items and calculated financial ratios.

\subsection{Variables and Hypotheses}

In this study, the selected variables (financial ratios and accounting figures) were obtained from the companies' balance sheets and income statements. Most of the selected variables were used in previous studies. (Agca ve Aktas, 2007; Callao et al., 2007; Lantto \& Sahlström, 2009; Gaston et al., 2010; Iatridis, 2010) The selected variables included ratios related to companies' liquidity, operating efficiency, financial structure and profitability. List of selected variables are presented in Appendix 2. We employed 17 financial ratios and 6 financial statement items in our analysis. These variables are categorized into two groups. Descriptive statistics are presented for each variable in Appendix 2.

The following hypothesis has been established to determine whether there is any difference on industrial basis between the variables which are derived from the financial statements prepared in accordance with different reporting standards.

$\mathbf{H}_{01}$ : There is no statistically significant difference between each calculated financial variable of local GAAP-based and IFRS-based financial statements.

The quantitative effects of different accounting standards on selected ISE listed companies' financial variables can be determined with Hypothesis $\mathrm{H}_{01}$. For this purpose, the variables of the same companies regarding the same periods were selected for the comparison of different reporting principles.

In order to test the first hypothesis of our study, we first determined whether the variables are normally distributed or not. We used Kolmogorov-Smirnov and Shapiro-Wilks tests for normal distribution tests (See Appendix 3). As a result of the analysis, we determined that the variables were not normally distributed $(p<0.05)$. Therefore, we used Wilcoxon signed-ranks test in order to determine the relationship between the non-parametric variables.

In this study, logistic regression analysis was employed for empirical analysis. However, Mann-Whitney U test was used for the selection of included variables. Mann-Whitney U test is a nonparametric test alternative to the Independent Samples T- test. We used dummy variable as the dependent variable in our test. In the model, financial variables calculated using IFRS-based financial statements are indicated as 1 , variables of local GAAP-based financial statements stated as 0 . The following logit model was used in this study.

$$
R R i, t=\frac{e^{B_{0}+B_{1} x_{1}+\cdots+B_{k} X_{k}}}{1+e^{B_{0}+B_{1} x_{1}+\cdots+B_{k} X_{k}}}
$$

The parameters in this model are;

$\mathrm{RR}_{\mathrm{i}, \mathrm{t}}=$ Dummy variable. IFRS-based reporting equals to 1, local GAAP-based reporting equals to 0 .

$\mathrm{B}_{0}=$ If the independent variable is equal to zero, this will be the dependent value (fixed value)

$\mathrm{B}_{1}, \mathrm{~B}_{2}, \ldots, \mathrm{B}_{\mathrm{k}}=$ The regression coefficients of the independent variables

$\mathrm{X}_{1}, \mathrm{X}_{2}, \ldots, \mathrm{X}_{\mathrm{k}}=$ independent variables

$\mathrm{k}=$ the number of independent variables

$\mathrm{e}=$ is equal to the constant of 2.71 .

$\mathbf{H}_{\mathbf{0} 2}$ : In terms of local GAAP and IFRS, book value/market value ratio does not differ statistically.

The book values are the total equity values of selected companies in accordance with local GAAP and IFRS. These values are compared with the market values of these companies. The ISE database was used for the calculation of the market values.

Market values are affected by economic, social and political circumstances. In Turkey, ISE-100 index 
consistently increased between 2002 and 2005. Closing values of ISE-100 index, on average, were 10,987 for year 2002, 12,258 for year 2003, 19,912 for year 2004 and 29,382 for year 2005. Therefore, we used the book value/market value ratio in the study.

In the analysis of the difference between the market values and the book values, local GAAP and IFRS figures were used for the calculation of the book values. As a result, the following equations were used to assess the statistical significance of the differences between the market values and the book values.

$$
\begin{gathered}
\text { Local GAAP }=\left[\text { Book Value }_{(\mathrm{GAAP})} / \text { Market Value }_{(\mathrm{GAAP})}\right] \\
\text { IFRS }=\left[\text { Book Value }_{(\mathrm{IFRS})} / \text { Market Value }_{(\mathrm{IFRS})}\right]
\end{gathered}
$$

We used Wilcoxon signed-ranks test in order to assess whether the book value/market value ratios derived from local GAAP and IFRS figures had statistically significant differences or not.

\section{Results and Discussion}

In this section, we first introduced the results on differences in financial reporting under local GAAP and IFRS. Next, we assessed the impacts of the local GAAP and IFRS on subsector groups. Thereafter, we analyzed the relationship between market values and book values in terms of local GAAP and IFRS.

\subsection{Differences in Financial Reporting under Local GAAP and IFRS}

In order to test the first hypothesis of this study, we identified whether the variables were normally distributed or not. The test results are presented in Appendix 3. When Appendix 3 was analyzed, we noted that the variables derived from the financial statements which were prepared according to different accounting standards, were not normally distributed $(\mathrm{p}<0.05)$. Therefore, we used Wilcoxon signed-ranks test. Wilcoxon signed-ranks test results are presented in Table 2 .

Table 2. Results of Wilcoxon signed ranks test

\begin{tabular}{lll|lll}
\hline Variables & Z-statistic & $\begin{array}{l}\text { Asymp. } \\
\text { Sig. }(2 \text {-tailed })\end{array}$ & Variables & Z-statistic & $\begin{array}{l}\text { Asymp. } \\
\text { Sig. }(2 \text {-tailed })\end{array}$ \\
\hline CUR & -2.426 & $0.015(* *)$ & SL/FA & -7.955 & $0.000(*)$ \\
QUR & -0.400 & 0.689 & EQ/TA & -5.677 & $0.000(*)$ \\
CAR & -10.263 & $0.000(*)$ & SL/EQ & -5.631 & $0.000(*)$ \\
INT & -0.937 & 0.349 & CL/TL & -4.482 & $0.000\left(^{*}\right)$ \\
RET & -2.426 & $0.015(*)$ & CL/TA & -7.692 & $0.000\left(^{*}\right)$ \\
AST & -6.192 & $0.000(*)$ & CA & -1.532 & 0.126 \\
TL/TA & -5.600 & $0.000(*)$ & INV & -4.310 & $0.000\left(^{*}\right)$ \\
LTL/CC & -2.042 & $0.041(*)$ & FA & -7.640 & $0.000\left(^{*}\right)$ \\
ROA & -2.215 & $0.027(*)$ & CL & -0.061 & 0.951 \\
ROE & -2.073 & $0.038(*)$ & LTL & -4.594 & $0.000\left(^{*}\right)$ \\
TL/EQ & -5.307 & $0.000(*)$ & EQ & -5.032 & $0.000\left(^{*}\right)$ \\
TL/TW & -5.829 & $0.000(*)$ & & & \\
\hline
\end{tabular}

Notes: (*) Significant at 1\% level; (**) significant at 5\% level.

When Table 2 was examined, it was identified that liquidity ratios, inventory turnovers, current assets and short-term liabilities did not have statistically significant differences. The other variables were determined to be significant at $1 \%$ and $5 \%$ levels. In the first phase of our study, Hypothesis 1 was accepted for liquidity ratios, inventory turnovers, current assets and short-term liabilities and rejected for other variables.

According to the results of Wilcoxon signed ranks test and the results presented in Appendix 2, we found that current ratios, liquidity ratios, return on assets, return on equity, debt ratios, equity to total assets ratios, equity turnover, tangibles assets and equity values increased during the transition to IFRS-based financial statements.

After assessing the effects of Wilcoxon test, we used Mann-Whitney U test in order to develop the logit model with statistically significant variables. Mann-Whitney U test results are presented in Table 3. The Mann-Whitney U-test results indicated that CAR and SL/FA variables were statistically significant at $1 \%$ error level, AST, $\mathrm{TL} / \mathrm{TW}, \mathrm{CL} / \mathrm{TL}$ and CL/TA variables were statistically significant at 5\% error level, and RET and SL/EQ variables were statistically significant at $10 \%$ error level.

According to the study, we tested the $\mathrm{H}_{01}$ hypothesis and we identified that financial ratios of local GAAP-based and IFRS-based financial statements had statistically significant differences. Thus, we were able to say that some 
financial variables had significant impacts on the quality and comparability of financial reporting. The study is also consistent with literature (Jermakowicz, 2004; Agca \& Aktas, 2007; Callao et al., 2007; Lantto \& Sahlström, 2009; Gaston et al., 2010; Iatridis, 2010).

Table 3. Results of Mann-Whitney test

\begin{tabular}{lll|lll}
\hline & & & & Asymp. \\
Variables & Z-statistic & Sig. (2-tailed) & Variables & Z-statistic & Sig. (2-tailed) \\
\hline CUR & -0.142 & 0.887 & SL/FA & -2.805 & $0.005(*)$ \\
CAR & -11.646 & $0.000(*)$ & EQ/TA & -1.449 & 0.147 \\
RET & -1.695 & $0.090(* * *)$ & SL/EQ & -1.805 & $0.071(* * *)$ \\
AST & -2.011 & $0.044(* *)$ & CL/TL & -2.300 & $0.021(* *)$ \\
TL/TA & -1.413 & 0.158 & CL/TA & -2.161 & $0.031(* *)$ \\
LTL/CC & -0.013 & 0.990 & INV & -0.524 & 0.600 \\
ROA & -0.878 & 0.380 & FA & -1.627 & 0.104 \\
ROE & -0.863 & 0.388 & LTL & -1.202 & 0.230 \\
TL/EQ & -0.993 & 0.321 & EQ & -1.551 & 0.121 \\
TL/TW & -2.146 & $0.032(* *)$ & & \\
\hline
\end{tabular}

Notes: (*) Significant at 1\% level; (**) significant at 5\% level; (***) significant at $10 \%$ level.

In our logit model, we selected the variables with high statistical significance $(p<0.10)$. Accordingly, the developed model is as follows:

$$
\mathrm{RR}_{\mathrm{i}, \mathrm{t}}=\mathrm{B}_{0}+\mathrm{B}_{1}(\mathrm{CAR})+\mathrm{B}_{2}(\mathrm{RET})+\mathrm{B}_{3}(\mathrm{AST})+\mathrm{B}_{4}(\mathrm{TL} / \mathrm{TW})+\mathrm{B}_{5}(\mathrm{SL} / \mathrm{FA})+\mathrm{B}_{6}(\mathrm{SL} / \mathrm{EQ})+\mathrm{B}_{7}(\mathrm{CL} / \mathrm{TL})+\mathrm{B}_{8}(\mathrm{CL} / \mathrm{TA})+\varepsilon
$$

In the application of logistic regression analysis, we used Forward Stepwise (Wald) method and included CAR variable in the first step and CL/TA variable in the second step. The model ended at the second step because there were no additional variables that could be added at this stage. Each variable's coefficients and significance levels are shown in Table 4.

Table 4. Results of logistic regression analysis

\begin{tabular}{llllll}
\hline Variables & B & S.E. & Wald & Sig. $(*)$ & $\operatorname{Exp}(\mathrm{B})$ \\
\hline Constant & 4.069 & 0.545 & 55.721 & 0.000 & 58.513 \\
CAR & -1.866 & 0.222 & 70.393 & 0.000 & 0.155 \\
CL/TA & -5.966 & 1.098 & 29.542 & 0.000 & 0.003 \\
\hline
\end{tabular}

Note: $(*)$ Significant at $1 \%$ level.

In logistic regression model, we found Nagelkerke $\mathrm{R}^{2}=0.56$ instead of linear regression $\mathrm{R}^{2}$. According to Nagelkerke $\mathrm{R}^{2}$, we identified a $56 \%$ relationship between dependent variables and independent variables. Moreover, the success rate of the correct classification of this model was determined to be $90 \%$. This high ratio indicates the effectiveness of the model.

\subsection{Sector of Operation}

We found that local GAAP and IFRS had impact on the manufacturing companies listed on the ISE, but the impact on sub-sectors was dissimilar. (see Table 1).

We were able to note that sub-sector groups had different results than the total sample groups in Table 5 . However, we identified that CAR and CL/TA variables were statistically significant for all sub-groups in the sector. The only exception was CL/TA variable not being statistically significant in the WFP sub-industry. In fact, this result is consistent with the results of the logistic regression in Table 6.

\subsection{Impact of IFRS on the Book-to-Market Ratio}

We analyzed the relationship between the market values of the selected companies and their book values calculated from the financial statements based on local GAAP and IFRS. For this purpose, we used book value/market value $(\mathrm{B} / \mathrm{M})$ ratio. Firstly, we identified whether $\mathrm{B} / \mathrm{M}$ ratio was normally distributed or not. As error values of Kolmogorov-Smirnov and Shapiro-Wilk test results were lower than 5\%, Wilcoxon signed ranks test was used. 
Table 5. Results of Wilcoxon signed ranks test for sector of operation

\begin{tabular}{|c|c|c|c|c|c|c|c|}
\hline Financial Variables & $\begin{array}{l}\text { FBT } \\
\text { (Z-statistic) }\end{array}$ & $\begin{array}{l}\text { TCL } \\
\text { (Z-statistic) }\end{array}$ & $\begin{array}{l}\text { WFP } \\
\text { (Z-statistic) }\end{array}$ & $\begin{array}{l}\text { PCR } \\
\text { (Z-statistic) }\end{array}$ & $\begin{array}{l}\text { STS } \\
\text { (Z-statistic) }\end{array}$ & $\begin{array}{l}\text { MEI } \\
\text { (Z-statistic) }\end{array}$ & $\begin{array}{l}\text { CER } \\
\text { (Z-statistic) }\end{array}$ \\
\hline CUR & -1.526 & -0.782 & -0.652 & -1.095 & $-2.746(*)$ & -0.459 & -1.326 \\
\hline QUR & $-2.953(*)$ & -0.161 & -0.663 & -0.330 & $-2.113(* *)$ & $-1.887(* *)$ & -0.187 \\
\hline CAR & $-3.823(*)$ & $-4.457(*)$ & $-2.934(*)$ & $-4.286(*)$ & $-4.457(*)$ & $-3.059(*)$ & $-4.074(*)$ \\
\hline INT & -0.035 & -0.105 & $-1.955(* * *)$ & -0.852 & -0.944 & -1.069 & -0.625 \\
\hline RET & -1.538 & $-1.664(* * *)$ & -1.274 & -0.849 & $-2.390(* *)$ & -0.533 & -0.241 \\
\hline AST & $-1.807(* * *)$ & $-3.486(*)$ & -0.296 & $-3.285(*)$ & $-2.191(* *)$ & $-2.708(*)$ & $-1.894(* * *)$ \\
\hline TL/TA & $-2.898(*)$ & $-2.680(*)$ & -0.979 & $-3.329(*)$ & -0.114 & $-2.275(* *)$ & $-2.549(* *)$ \\
\hline LTL/CC & $-3.743(*)$ & -0.800 & -1.156 & $-1.686(* * *)$ & $-2.600(*)$ & -1.020 & -1.390 \\
\hline ROA & -1.138 & -0.179 & -1.051 & -1.165 & -0.876 & -1.126 & -0.349 \\
\hline ROE & -1.154 & -0.214 & -0.051 & $-1.943(* * *)$ & -0.380 & $-2.244(* *)$ & -0.093 \\
\hline TL/EQ & $-2.777(*)$ & $-1.867(* * *)$ & -1.156 & $-2.000(* *)$ & -0.013 & $-2.118(* *)$ & $-2.971(*)$ \\
\hline $\mathrm{TL} / \mathrm{TW}$ & $-2.461(*)$ & $-2.700(*)$ & -1.423 & $-3.343(*)$ & -0.955 & $-1.766(* * *)$ & $-2.403(* *)$ \\
\hline SL/FA & $-2.627(*)$ & $-4.029\left(^{*}\right)$ & -0.560 & $-4.107(*)$ & $-2.636(*)$ & $-3.059(*)$ & $-3.099\left(^{*}\right)$ \\
\hline $\mathrm{EQ} / \mathrm{TA}$ & $-2.898(*)$ & $-2.832(*)$ & -0.765 & $-3.586(*)$ & -0.371 & $-2.275(* *)$ & $-2.614(*)$ \\
\hline SL/EQ & $-2.093(* *)$ & $-2.552(* *)$ & -1.334 & $-2.171(* *)$ & -1.457 & $-2.275(* *)$ & $-2.516(* *)$ \\
\hline $\mathrm{CL} / \mathrm{TL}$ & -0.785 & -1.486 & $-2.223(* *)$ & $-1.729(* * *)$ & $-3.643(*)$ & -0.549 & -1.380 \\
\hline $\mathrm{CL} / \mathrm{TA}$ & $-2.036(* *)$ & $-3.864(*)$ & -1.245 & $-3.835(*)$ & $-3.060(*)$ & $-2.594(*)$ & $-3.249(*)$ \\
\hline $\mathrm{CA}$ & -1.198 & -0.860 & -0.153 & -0.483 & -1.201 & -0.357 & -0.017 \\
\hline INV & $-2.272(* *)$ & $-1.782(* * *)$ & -0.889 & $-1.888(* * *)$ & $-1.992(* *)$ & -0.674 & -1.368 \\
\hline FA & $-2.809(*)$ & $-3.857(*)$ & -1.007 & $-4.167(*)$ & $-2.029(* *)$ & $-3.059(*)$ & $-2.597(*)$ \\
\hline $\mathrm{CL}$ & $-2.485(* *)$ & -0.330 & -0.889 & -0.295 & -0.958 & -0.770 & -0.560 \\
\hline LTL & -0.161 & -1.629 & -1.423 & $-2.229(* *)$ & $-3.592(*)$ & -0.392 & $-2.346(* *)$ \\
\hline EQ & $-2.817(*)$ & $-2.781(*)$ & -0.889 & $-3.029(*)$ & -0.600 & $-2.197(* *)$ & -1.412 \\
\hline
\end{tabular}

Notes: $\left(^{*}\right)$ Significant at $1 \%$ level; $(* *)$ significant at $5 \%$ level; $(* * *)$ significant at $10 \%$ level.

Table 6. Book value vs. market value

\begin{tabular}{lll}
\hline B/M Ratios & Z-statistic & $\begin{array}{l}\text { Asymp. } \\
\text { Sig. (2-tailed) }\end{array}$ \\
\hline Observations related to 140 firms & & 0.872 \\
FBT & -0.161 & 0.717 \\
TCL & -0.362 & $0.062(* *)$ \\
WFP & -1.867 & $0.075(* *)$ \\
PCR & -1.778 & 0.290 \\
STS & -1.057 & $0.025\left(^{*}\right)$ \\
MEI & -2.236 & 0.433 \\
CER & -0.784 & 0.277 \\
\hline
\end{tabular}

Notes: $(*)$ Significant at $5 \%$ level; $(* *)$ significant at $10 \%$ level.

We found that local GAAP-based and IFRS-based financial statements do not statistically affect the B/M ratios of the selected companies according to Table 6 . These results were in line with the results of Hung and Subramanyam (2007). However; after analyzing the sub-sectors of manufacturing industry, we noted that the effect of transition for the stone and soil industry was in 5\% error level; for the textile, apparel and leather clothing industry, wood products industry, and furniture and paper products industries were in $10 \%$ error level. These results are compatible with the results of the studies conducted by Callao et al. (2007), Gaston et al. (2007) and Jarva and Lantto (2010).

In our study, we tested the $\mathrm{H}_{02}$ hypothesis and we observed no statistically significant differences of book value/market value ratios in terms of local GAAP-based and IFRS-based financial statements. After analyzing the sub-sectors of the manufacturing industry, we noted that $\mathrm{H}_{02}$ hypothesis was rejected for TCL, WFP and STS sub-industries; however, the hypothesis was accepted for FBT, PCR, MEI and CER sub-industries.

\section{Conclusion}

In this study, we analyzed the differences between local GAAP-based and IFRS-based financial statements of 
140 companies listed on the ISE, with the help of financial ratios and accounting figures. Thereafter, we examined the effect of IFRS on financial reporting. For this purpose, we used book value/market value ratio. The accounting figures of the selected companies helped us to assess the financial structure of these companies.

We identified the statistical comparability of differences of local GAAP-based and IFRS-based financial statements of manufacturing companies listed on the ISE. In other words, we noted that IFRS adoption had important impacts on financial reporting. The effects on inventories, fixed assets, long-term liabilities, and shareholders' equity accounts in the financial statements were at the significant level. The study by Callao et al. (2007) showed that adoption of IFRS had significant impacts on long-term liabilities and shareholders' equity accounts; however, there were no significant effects on fixed assets and inventories accounts. Gaston et al. (2007) determined that IFRS-based financial statements had statistically significant effects on fixed assets, long-term liabilities, and shareholders' equity accounts.

We identified significant differences between local GAAP-based and IFRS-based financial statements on current ratios, receivables turnover, assets turnover, total liabilities/tangible assets ratios, fixed assets turnover, equity turnover, short-term liabilities/total liabilities ratios, short-term liabilities/total assets ratios. In our sub-sector analysis, we determined that current ratios and short-term liabilities/total assets ratios were affected from the transition on financial reporting. Indeed, in their studies, Agca and Aktas (2007) and Callao et al. (2007) indicated that current ratios were influenced by the IFRS adoption on financial statements.

We found no statistically significant differences in book value/market value ratio analysis depending on the market value under local GAAP-based and IFRS-based financial statements. In literature, Arce and Mora (2002), Callao et al. (2007), Gaston et al. (2007) and Jarva and Lantto (2010) identified statistically significant differences about B/M between local GAAP-based and IFRS-based financial statements. However, Hung and Subramanyam (2007) determined that book value was not influenced from IFRS transition. We examined that $\mathrm{B} / \mathrm{M}$ ratios of TCL, WFP and STS sub-industries were affected from IFRS transition whereas the same ratios of FBT, PCR, MEI and CER sub-industries were not affected from IFRS transition.

The results of the study showed that adoption of IFRS had a statistically significant effect on the equity accounts. Hence, we identified that transition to IFRS provided the opportunity for capital maintenance and the protection against failure risk.

We believe that the business managers, analysts and creditors may find this study useful for IFRS transition in accordance with Law No. 6102, effective on 2013. In addition, the regulatory agencies may find this study beneficial for the harmonization process of IFRS.

There were some limitations in this study. First of all, in our analysis, we only considered the transition periods. Therefore, time period was limited. In addition, we only included the manufacturing companies listed on the ISE. The selected sample size was limited when compared to all of the companies operating in the manufacturing industry. Our study did not allow us to measure the impact of each standard on the financial ratios and accounting figures. Considering these constraints may provide more accurate results in future studies.

\section{Acknowledgements}

We would like to thank the editors and anonymous referees for the helpful comments and suggestions during the review process.

\section{References}

Agca, A., \& Aktas, R. (2007). First time application of IFRS and its impact on financial ratios: a study on Turkish listed firms. Problems and Perspectives in Management, 5(2), 99-112.

Arce, M., \& Mora, A. (2002). Empirical evidence of the effect of European accounting differences on the stock market valuation of earnings and book value. The European Accounting Review, 11(3), 573-599. http://dx.doi.org/10.1080/09638180220125616

Callao, S., Jarne, J. I., \& Lainez, J. (2007). Adoption of IFRS in Spain: Effect on the comparability and relevance of financial reporting. Journal of International Accounting, Auditing and Taxation, 16, 148-178. http://dx.doi.org/10.1016/j.intaccaudtax.2007.06.002

Floropoulos, I. (2006). IFRS. First time users: Some empirical evidence from Greek companies. Spoudai: Journal of Economics and Business, 56(3), 39-70.

Gaston, S. C., Garcia, C. F., Jarne, J. I., \& Gadea, J. A. (2010). IFRS adoption in Spain and the United Kingdom: effects on accounting numbers and relevance. Advances in Accounting, Incorporating Advances in International Accounting, 26, 304-313. http://dx.doi.org/10.1016/j.adiac.2010.08.003 
Guggiola, G. (2010). IFRS adoption in the E.U., accounting harmonization and markets efficiency: a review. International Business \& Economics Research Journal, 9(12), 99-112.

Harris, M. S., \& Muller, K. A. (1999). The market valuation of IAS versus US-GAAP accounting measures using Form 20-F reconciliations. Journal of Accounting and Economics, 26, 285-312. http://dx.doi.org/10.1016/S0165-4101(99)00003-8

Harris, T. S., Lang, M., \& Moller, H. P. (1994). The value relevance of German accounting measures: an empirical analysis. Journal of Accounting Research, 32(2), 187-209. http://dx.doi.org/10.2307/2491281

Haverals, J. (2007). IAS/IFRS in Belgium: quantitative analysis of the impact on the tax burden of companies. Journal of International Accounting, Auditing and Taxation, 16, 69-89. http://dx.doi.org/10.1016/j.intaccaudtax.2007.01.005

Hung, M., \& Subramanyam, K. R. (2007). Financial statement effects of adopting international accounting standards: the case of Germany. Review of Accounting Studies, 12(4), 623-657. http://dx.doi.org/10.1007/s11142-007-9049-9

Iatridis, G. (2010). IFRS adoption and financial statement effects: the UK case. International Research Journal of Finance and Economics, 38, 165-172.

Jarva, H., \& Lantto, A. M. (2010). The value-relevance of IFRS versus domestic accounting standards: evidence from Finland. Retrieved from http://ssrn.com/abstract=1588087

Jermakowicz, E. K. (2004). Effects of adoption of international financial reporting standards in Belgium: the evidence from BEL-20 companies. Accounting in Europe, 1(1), 51-70. http://dx.doi.org/10.1080/0963818042000270811

Jermakowicz, E. K., Prather-Kinsey, J., \& Wulf, I. (2007). The Value relevance of accounting income reported by DAX-30 German companies. Journal of International Financial Management and Accounting, 18(3), 151-191. http://dx.doi.org/10.1111/j.1467-646X.2007.01011.x

Kabir, M. H., Laswad, F., \& Islam, M. A. (2010). Impact of IFRS in New Zealand on accounts and earnings $\begin{array}{lllll}\text { quality. Australian } & \text { Accounting }\end{array}$ http://dx.doi.org/10.1111/j.1835-2561.2010.00106.x

Karapinar, S., Canel, C., \& Oktem, R. (2012). A survey of accounting culture in Turkey. Advances In Management, 2(12), 42-49.

Lantto, A. M., \& Sahlström, P. (2009). Impact of international financial reporting standard adoption on key financial ratios. Accounting and Finance, 49, 341-361. http://dx.doi.org/10.1111/j.1467-629X.2008.00283.x

Mirza, A. A., Holt, G. J., \& Orrel, M. (2006). IFRS: Workbook and Guide. USA: John Wiley \& Son Inc.

Niskanen, J., Kinnunen, J., \& Kasanen, E. (2000). The value relevance of IAS reconciliation components: empirical evidence from Finland. Journal of Accounting and Public Policy, 19, 119-137. http://dx.doi.org/10.1016/S0278-4254(00)00002-8

Terzi, S. (2008). Application of Turkish financial reporting standards: an example of industry enterprise. Mali Çözüm Journal (Financial Analysis Journal), 17(88), 59-85.

Terzi, S. (2011). Applications of financial reporting in the European Union and Italy. Journal of Administrative Sciences, 9(1), 273-290.

Terzi, S., Kiymetli Sen, I., \& Bulbul, F. (2007). The opening balance sheet preparation to first-time adapts IFRS in Turkey. Mali Çözüm Journal (Financial Analysis Journal), 17(81), 103-129.

Terzi, S., Kiymetli Sen, I., \& Bulbul, F. (2008). How to prepare balance sheet and income statement under the IFRS. Mali Çözüm Journal (Financial Analysis Journal), 18(90), 103-129.

Zeghal, D., Chtourou, S., \& Sellami, Y. M. (2011). An analysis of the effect of mandatory adoption of IAS/IFRS on earnings managements. Journal of International Accounting, Auditing and Taxation, 20, 61-72. http://dx.doi.org/10.1016/j.intaccaudtax.2011.06.001 


\section{Appendix}

Appendix 1. Key differences between Turkish Accounting System and IFRS

\begin{tabular}{l} 
Item \\
\hline $\begin{array}{l}\text { Measurement of } \\
\text { financial instruments }\end{array}$ \\
Measurement of \\
inventories \\
Measurement of \\
property, plant and \\
equipment, intangible \\
assets
\end{tabular}

TAS treatment IFRS treatment

Financial instruments are measured IAS 39:

Financial instruments are measured IAS 39:

with recorded values.

Financial instruments are measured with redemption values or fair values.

Inventories are measured with cost IAS 2:

values. Inventory impairments are rarely used in nonrecurring

Inventories are measured with lesser of costs or net realizable values circumstances.

(NRV). Inventory impairments are used when book values are greater

These assets are measured with than NRVs.

acquisition costs. No revaluation is available. Residual values are not used in amortization.

Normal and accelerated amortizations are the only accepted methods. Start-up and restructuring costs are able to be capitalized.

Impairment of assets Impairments of tangible and intangible assets are not allowed.

IAS 16 and IAS 38:

These assets can be measured with acquisition costs or fair values. Revaluation is available if the value of assets increased at the material level. Residual values are used in amortization. Normal, unit-of-production, and accelerated amortizations are accepted methods. Start-up and restructuring costs are included in income statements.

Goodwill and

Impairment

Goodwill is measured with recorded value.

Goodwill is amortized.

Measurement of Writing-down of provisions is provisions discretionary and conditional. For example, legal provisions are only available if court process already started.

Measurement of Provision for severance pay is employee benefits calculated if employee leaves the company.

Measurement of Only current income tax liability is measured in financial statements.

\section{IAS 36:}

Impairments of assets are used if net recoverable values are less than book values.

IFRS 3, IAS 38 and IAS 36:

Fair value is used in goodwill calculation. Goodwill cannot be amortized. Impairment test is used.

IAS 37:

Provisions are recorded as liability if some conditions are realized. Assumptions are revised each period.

IAS 19:

Each reporting period, provision of severance pay is calculated with actuarial assumptions.

IAS 12:

Current income tax liability and deferred tax assets/liabilities are measured in financial statements.

Measurement of

Revenue is measured with gross value.

IAS 18:

revenue

Deferred interest is included in revenue.

Revenue is measured with fair value. Deferred interest is separated from revenue.

Measurement of Borrowing costs are included into tangible and intangible assets.

R\&D expenditure

Research and Development (R\&D) expenditures are recognized as an asset in particular circumstances.

Extraordinary income and expense

Expenses are classified as ordinary and extraordinary in income statement.

Non-controlling

interest

Non-controlling interest is not calculated.

Investment in associates, joint ventures
Investment in associates and joint ventures are measured with recorded values.
IAS 23:

Borrowing costs are included into assets during the period of time to get ready for its intended use or sale. Other borrowing costs are recognized as an expense in other comprehensive income.

IAS 38:

Research expenditures cannot be recognized as an asset. Development expenditures are recognized as an asset in particular circumstances.

IAS 1:

There are no extraordinary expenses in comprehensive income statement.

IFRS 10:

Non-controlling interest is reported as a separate item in consolidated financial statement.

IAS 28 and IFRS 11:

Assets are measured with equity method. Investment account is revised during profit or loss changes of investments every period. 
Appendix 2. Descriptive statistics for variables under Local GAAP and IFRS

\begin{tabular}{|c|c|c|c|c|c|c|c|c|}
\hline \multirow[b]{2}{*}{ Financial Ratios } & \multicolumn{4}{|c|}{ Local GAAP } & \multicolumn{4}{|l|}{ IFRS } \\
\hline & Mean & $\begin{array}{l}\text { Std. } \\
\text { Deviation }\end{array}$ & Min. & Max. & Mean & $\begin{array}{l}\text { Std. } \\
\text { Deviation }\end{array}$ & Min. & Max. \\
\hline Current Ratio (CUR) & 2.113 & 1.689 & 0.355 & 13.282 & 2.240 & 2.005 & 0.272 & 13.282 \\
\hline Quick Ratio (QUR) & 1.442 & 1.358 & 0.129 & 11.266 & 1.491 & 1.499 & 0.124 & 11.266 \\
\hline Cash Ratio (CAR) & 2.218 & 1.900 & 0.355 & 13.296 & 0.545 & 1.163 & 0.000 & 9.384 \\
\hline Inventory Turnover (INT) & 8.121 & 14.792 & 0.695 & 126.983 & 7.645 & 14.033 & -3.560 & 133.699 \\
\hline Receivables Turnover (RET) & 9.229 & 17.235 & 1.151 & 153.655 & 8.572 & 16.935 & 0.308 & 153.655 \\
\hline Assets Turnover (AST) & 1.102 & 0.782 & 0.127 & 8.570 & 0.981 & 0.571 & 0.117 & 5.322 \\
\hline $\begin{array}{l}\text { Total Liabilities to Total Assets } \\
\text { (TL/TA) }\end{array}$ & 0.494 & 0.315 & 0.044 & 2.428 & 0.448 & 0.287 & 0.040 & 2.384 \\
\hline $\begin{array}{l}\text { Long Term Liabilities to Continuous } \\
\text { Capital (LTL/CC) }\end{array}$ & 0.227 & 0.366 & -2.163 & 1.932 & 0.194 & 0.327 & -2.503 & 1.351 \\
\hline Return on Assets (ROA) & 0.029 & 0.097 & -0.356 & 0.265 & 0.046 & 10.097 & -85.305 & 77.214 \\
\hline Return on Equity (ROE) & -0.507 & 6.045 & -71.382 & 1.479 & -0.095 & 23.155 & -211.448 & 162.659 \\
\hline Total Liabilities to Equity (TL/EQ) & -2.675 & 44.398 & -523.210 & 11.918 & 0.325 & 8.022 & -90.672 & 15.308 \\
\hline $\begin{array}{l}\text { Total Liabilities to Tangible Worth } \\
\text { (TL/TW) }\end{array}$ & 1.855 & 2.706 & 0.086 & 24.498 & 1.401 & 2.299 & 0.086 & 24.465 \\
\hline Sales to Fixed Assets (SL/FA) & 2.932 & 3.097 & 0.205 & 24.713 & 2.230 & 2.149 & 0.190 & 17.537 \\
\hline Equity to Total Assets (EQ/TA) & 0.489 & 0.313 & -1.428 & 0.956 & 0.535 & 0.288 & -1.384 & 0.960 \\
\hline Sales to Equity (SL/EQ) & -3.283 & 57.296 & -664.658 & 16.343 & 1.695 & 4.258 & -41.178 & 14.714 \\
\hline $\begin{array}{l}\text { Current Liabilities to Total } \\
\text { Liabilities (CL/TL) }\end{array}$ & 0.721 & 0.188 & 0.239 & 0.996 & 0.665 & 0.206 & 0.250 & 0.997 \\
\hline $\begin{array}{l}\text { Current Liabilities to Total Assets } \\
\text { (CL/TA) }\end{array}$ & 0.342 & 0.216 & 0.037 & 1.451 & 0.294 & 0.204 & 0.025 & 1.395 \\
\hline $\begin{array}{l}\text { Accounting Figures (all numbers } \\
\text { in one million Turkish Lira) }\end{array}$ & & & & & & & & \\
\hline Current Assets (CA) & 164,465 & 435,847 & 1,996 & $3,123,995$ & 156,007 & 400,607 & 1,607 & $2,681,244$ \\
\hline Inventories (INV) & 48,855 & 146,754 & 265 & $1,270,684$ & 48,950 & 131,204 & 302 & 987,426 \\
\hline Fixed Assets (FA) & 166,253 & 429,502 & 2,778 & $3,729,600$ & 219,148 & 507,995 & 830 & $3,896,590$ \\
\hline Current Liabilities (CL) & 111,653 & 311,974 & 812 & $2,083,492$ & 110,788 & 316,498 & 815 & $2,379,131$ \\
\hline Lon Term Liabilities (LTL) & 42,461 & 107,818 & 18 & 757,982 & 50,113 & 114,738 & 18 & 860,886 \\
\hline Equity (EQ) & 164,536 & 478,478 & $-45,396$ & $4,361,434$ & 202,171 & 501,172 & $-44,753$ & $4,541,443$ \\
\hline
\end{tabular}

Appendix 3. Results of normality test

\begin{tabular}{|c|c|c|c|c|c|c|c|c|c|c|c|}
\hline \multirow[t]{2}{*}{ Variables } & & \multicolumn{2}{|c|}{ Kolmogorov-Smirnov } & \multicolumn{2}{|c|}{ Shapiro-Wilk } & \multicolumn{2}{|c|}{ Variables } & \multicolumn{2}{|c|}{ Kolmogorov-Smirnov } & \multicolumn{2}{|c|}{ Shapiro-Wilk } \\
\hline & & Statistic & Sig. & Statistic & Sig. & & & Statistic & Sig. & Statistic & Sig. \\
\hline \multirow[t]{2}{*}{ CUR } & GAAP & 0.192 & 0.000 & 0.724 & 0.000 & SL/FA & GAAP & 0.208 & 0.000 & 0.613 & 0.000 \\
\hline & IFRS & 0.219 & 0.000 & 0.696 & 0.000 & & IFRS & 0.187 & 0.000 & 0.682 & 0.000 \\
\hline \multirow[t]{2}{*}{ QUR } & GAAP & 0.208 & 0.000 & 0.693 & 0.000 & $\mathrm{EQ} / \mathrm{TA}$ & GAAP & 0.080 & 0.028 & 0.859 & 0.000 \\
\hline & IFRS & 0.208 & 0.000 & 0.702 & 0.000 & & IFRS & 0.110 & 0.000 & 0.821 & 0.000 \\
\hline \multirow[t]{2}{*}{ CAR } & GAAP & 0.205 & 0.000 & 0.707 & 0.000 & SL/EQ & GAAP & 0.475 & 0.000 & 0.097 & 0.000 \\
\hline & IFRS & 0.320 & 0.000 & 0.488 & 0.000 & & IFRS & 0.331 & 0.000 & 0.407 & 0.000 \\
\hline \multirow[t]{2}{*}{ INT } & GAAP & 0.321 & 0.000 & 0.330 & 0.000 & $\mathrm{CL} / \mathrm{TL}$ & GAAP & 0.155 & 0.000 & 0.919 & 0.000 \\
\hline & IFRS & 0.317 & 0.000 & 0.322 & 0.000 & & IFRS & 0.066 & 0.200 & 0.959 & 0.000 \\
\hline \multirow[t]{2}{*}{ RET } & GAAP & 0.320 & 0.000 & 0.308 & 0.000 & $\mathrm{CL} / \mathrm{TA}$ & GAAP & 0.084 & 0.017 & 0.874 & 0.000 \\
\hline & IFRS & 0.319 & 0.000 & 0.318 & 0.000 & & IFRS & 0.096 & 0.003 & 0.825 & 0.000 \\
\hline \multirow[t]{2}{*}{ AST } & GAAP & 0.185 & 0.000 & 0.555 & 0.000 & $\mathrm{CA}$ & GAAP & 0.367 & 0.000 & 0.336 & 0.000 \\
\hline & IFRS & 0.125 & 0.000 & 0.765 & 0.000 & & IFRS & 0.360 & 0.000 & 0.342 & 0.000 \\
\hline \multirow[t]{2}{*}{ TL/TA } & GAAP & 0.087 & 0.011 & 0.852 & 0.000 & INV & GAAP & 0.370 & 0.000 & 0.278 & 0.000 \\
\hline & IFRS & 0.123 & 0.000 & 0.807 & 0.000 & & IFRS & 0.334 & 0.000 & 0.410 & 0.000 \\
\hline \multirow[t]{2}{*}{ LTL/CC } & GAAP & 0.255 & 0.000 & 0.697 & 0.000 & FA & GAAP & 0.352 & 0.000 & 0.357 & 0.000 \\
\hline & IFRS & 0.263 & 0.000 & 0.603 & 0.000 & & IFRS & 0.331 & 0.000 & 0.429 & 0.000 \\
\hline \multirow[t]{2}{*}{ ROA } & GAAP & 0.115 & 0.000 & 0.951 & 0.000 & $\mathrm{CL}$ & GAAP & 0.370 & 0.000 & 0.329 & 0.000 \\
\hline & IFRS & 0.474 & 0.000 & 0.166 & 0.000 & & IFRS & 0.159 & 0.000 & 0.914 & 0.000 \\
\hline \multirow[t]{2}{*}{ ROE } & GAAP & 0.444 & 0.000 & 0.084 & 0.000 & LTL & GAAP & 0.347 & 0.000 & 0.387 & 0.000 \\
\hline & IFRS & 0.464 & 0.000 & 0.168 & 0.000 & & IFRS & 0.367 & 0.000 & 0.336 & 0.000 \\
\hline \multirow[t]{2}{*}{ TL/EQ } & GAAP & 0.474 & 0.000 & 0.083 & 0.000 & EQ & GAAP & 0.337 & 0.000 & 0.304 & 0.000 \\
\hline & IFRS & 0.450 & 0.000 & 0.180 & 0.000 & & IFRS & 0.370 & 0.000 & 0.278 & 0.000 \\
\hline \multirow[t]{2}{*}{$\mathrm{TL} / \mathrm{TW}$} & GAAP & 0.257 & 0.000 & 0.503 & 0.000 & & & & & & \\
\hline & IFRS & 0.286 & 0.000 & 0.395 & 0.000 & & & & & & \\
\hline
\end{tabular}

